\title{
PENGARUH PEMBERIAN BORAKS PERORAL SUB AKUT TERHADAP TERJADINYA ATROFI TESTIS TIKUS PUTIH JANTAN (RATTUS NOVERGICUS STRAIN WISTAR)
}

\author{
Diana Mayasari ${ }^{1}$, Nanang Mardiroharjo ${ }^{2}$ \\ Fakultas Kedokteran Universitas Muhammadiyah Malang, J1 Bendungan Sutami No. 188A Kota Malang \\ Kode Pos 65144, Indonesia
}

\begin{abstract}
ABSTRAK
Pengaruh Pemberian Boraks Peroral Sub Akut Terhadap Terjadinya Atrofi Testis Tikus Putih Jantan (Rattus novergicus strain wistar). Latar Belakang: Penggunaan boraks banyak disalahgunakan pada makanan. Boraks merupakan salah satu bahan toksik bagi organ testis sehingga dapat menyebabkan atrofi testis melalui penghambatan spermatogenesis. Tujuan: Membuktikan pengaruh pemberian boraks peroral sub akut terhadap terjadinya atrofi testis tikus putih jantan (Rattus novergicus strain wistar) dengan mengukur diameter testis, berat testis, dan jumlah tubulus seminiferus perlapangpandang. Metode: Eksperimental, The Post Test Only Control Group Design. Sampel yang digunakan 24 ekor dibagi 4 kelompok. Kelompok 1 (kontrol negatif), kelompok 2,3,dan 4 masing-masing dengan dosis 400 mg/kgBB, 500 $\mathrm{mg} / \mathrm{kgBB}$, dan $600 \mathrm{mg} / \mathrm{kgBB}$ selama 28 hari. Dianalisis dengan oneway ANOVA, uji korelasi, dan uji regresi. Hasil penelitian dan diskusi: Terdapat perbedaan diameter testis dan jumlah tubulus seminiferus masing-masing dengan sig $\mathrm{p}=0,020(\mathrm{p}<0,05)$ dan sig $\mathrm{p}=0,00(\mathrm{p}<0,05)$, sedangkan pada berat testis tidak terdapat perbedaan dengan sig $\mathrm{p}=0,744$ $(\mathrm{p}>0,05)$. Analisis korelasi diameter testis $(\mathrm{p}=0,001),(\mathrm{r}=-0,613)$, jumlah tubulus $(\mathrm{p}=0,000),(\mathrm{r}=0,828)$, kenaikan boraks menyebabkan penurunan diameter testis dan peningkatan jumlah tubulus. Analisis regresi R2 diameter testis $=0,376$ dan R2 jumlah tubulus=0,685. Pada penelitian ini pengaruh boraks terlihat pada gambaran mikroskopis dibandingkan makroskopis, hal ini disebabkan oleh waktu paparan boraks yang kurang lama. Kesimpulan: Pemberian boraks peroral sub akut berpengaruh terhadap atrofi testis.Kata Kunci: Ekstrak rimpang temulawak, Staphylococcus aureus, KHM (Kadar Hambat Minimum), KBM (Kadar Bunuh Minimum).
\end{abstract}

\begin{abstract}
The effects of sub-acute peroral borax to the occurrence of testicular atrophy of male white rats (Rattus novergicus wistar strain). Background: The use of borax is much abused on food. Borax was one of toxic for testicular organs so that it can cause testicular atrophy through inhibition of spermatogenesis Objective: Prove the effects of sub-acute peroral borax to the occurrence of testicular atrophy of male white rats (Rattus novergicus wistar strain) by measuring the diameter of testicular, the weight of testicular, and the number of seminiferous tubules each field of view. Methods: Experimental, The Post Test Only Control Group Design. The samples used are 24 rats which are divided into 4 groups. The first group (negative control), the second,third, and fourth group are respectively given a dose of $400 \mathrm{mg} / \mathrm{kg}, 500 \mathrm{mg} / \mathrm{kg}$, and $600 \mathrm{mg} / \mathrm{kg}$ for 28 days. Those are analyzed by oneway ANOVA, correlation test and regression test. Results and discussion: There is differences in the diameter of testicular and each amount of the seminiferous tubules with sig $p=0.020(p<0.05)$ and sig $p=0.00(p<0.05)$, whereas there is no difference in the weight of testicular with sig $p=0.744$ ( $p>0.05)$. Correlation analysis of the testicular diameter $(p=0.001),(r=0.613)$, the number of tubules $(p$ $=0.000),(r=0.828)$, the increase in borax causes a decrease of testicular diameter and an increase in the number of tubules. Regression analysis R2 the diameter of testicular $=0.376$ and R2 the number of tubules=0,685. In this study, the effects of borax are seen on microscopic view rather than macroscopic one, This is caused by a lack time of exposure to borax. Conclusion: Giving of sub acute peroral borax affects on testicular atrophy.
\end{abstract}

Key words: Borax, Testicular Atrophy, diameter of testicular, weight of testicular, and number of seminiferous tubules.

\section{PENDAHULUAN}

Infertilitas adalah suatu penyakit sistem reproduksi yang ditandai dengan tidak terjadinya kehamilan setelah melakukan hubungan seksual selama 12 bulan atau lebih (Hochschild dkk, 2009). Kejadian infertilitas semakin tahun semakin bertambah berdasarkan penelitian yang dilakukan oleh Mascarenhas dkk (2012) di 190 negara maju dan berkembang dari tahun 1990 - 2010 menunjukan peningkatan angka infertilitas dari 39,6 juta menjadi 52,6 juta. World Health Organization (WHO) juga memperkirakan sekitar 50 - 80 juta pasangan suami istri (1 dari 7 pasangan) mempunyai masalah infertilitas, dan setiap tahun muncul sekitar 2 juta pasangan infertil (WHO, 2012).

Angka kejadian infertilitas di Indonesia setiap tahun meningkat sebanyak $10-15 \%$ serta penyebab infertilitas sebanyak $40 \%$ berasal dari pria, $40 \%$ dari wanita, $10 \%$ dari 
pria dan wanita, dan $10 \%$ tidak diketahui berdasarkan hasil penelitian yang dilakukan oleh Bennet dkk (2012). Infertilitas pada pria dapat disebabkan oleh berbagai faktor diantaranya terjadinya infeksi di sistem reproduksi, merokok, radiasi, temperatur skrotum, reactive oxygen species (ROS), obatobatan, dan bahan-bahan lain yang bersifat toksik pada sistem reproduksi (Olayemi, 2010)

Boraks adalah salah satu bahan yang bersifat toksik bagi sistem reproduksi pria karena dapat menghambat spermatogenesis yang mengakibatkan terjadinya infertilitas (PMRA, 2012). Boraks merupakan suatu senyawa yang berbentuk kristal, warna putih, tidak berbau, larut dalam air dan stabil pada suhu dan tekanan normal. Boraks biasanya digunakan untuk pengawet dan anti jamur kayu, sebagai antiseptik, dan pembasmi kecoa (Syah, 2005). Namun di negara berkembang seperti di Indonesia boraks sering disalahgunakan oleh industri pangan sebagai bahan tambahan makanan untuk menambah rasa dan keawetan makanan (Oktavia, 2012).

Berdasarkan hasil pengujian laboratorium pada 3.206 sampel produk Pangan Jajanan Anak Sekolah (PJAS) yang diambil dari 866 Sekolah Dasar/ Madrasah Ibtidaiyah yang tersebar di 30 kota di Indonesia Selama tahun 2011 diketahui bahwa $94(2,93 \%)$ sampel mengandung boraks dan 43 $(1,34 \%)$ sampel mengandung formalin yang terdapat pada mie basah, bakso, kudapan dan makanan ringan (BPOM, 2011). YLKI (Yayasan Lembaga Konsumen Indonesia) melalui Warta Konsumen melaporkan, sekitar 86,49 persen sampel mi basah yang diambil di Yogyakarta, Semarang, dan Surabaya mengandung boraks. Lalu 76,9 persen mi basah mengandung boraks dan formalin secara bersamasama (YLKI, 2011).

Pest Management Regulatory Agency (PMRA) menyatakan bahwa laporan untuk sementara target utama pemberian boraks dengan jangka waktu pendek adalah organ testis (PMRA, 2012). Pada penelitian terdahulu yang dilakukan oleh Fukuda, dkk (2000) bahwa dengan pemberian boraks dengan dosis $300 \mathrm{mg} / \mathrm{KgBB}$ dan $500 \mathrm{mg} / \mathrm{KgBB}$ dengan jangka waktu 28 hari pada tikus dapat menimbulkan atrofi tubulus seminiferus menyeluruh.

\section{BAHAN DAN METODE}

\section{Penentuan Dosis}

Pada penelitian ini dosis boraks yang digunakan adalah dosis maksimal yang bisa meyebabkan atrofi testis pada penelitian terdahulu oleh Fukuda dkk (2000) pada hewan coba tikus yaitu $500 \mathrm{mg} / \mathrm{kgBB} / \mathrm{hari}$.

$$
\begin{aligned}
& =500 \mathrm{mg} \times 0,2 \mathrm{~kg} \\
& =100 \mathrm{mg} / \text { hari }
\end{aligned}
$$

Boraks yang digunakan pada penelitian ini adalah boraks berbentuk serbuk yang dicampur dengan air. Cara pembuatan campuran boraks dengan air yaitu :

$$
\begin{aligned}
& =5 \mathrm{~W} / \mathrm{V} \% \text { air } \\
& =5 \mathrm{gr} \text { boraks } / 100 \mathrm{ml} \text { air }
\end{aligned}
$$

Jadi boraks yang digunakan dalam penelitian ini: Kelompok 1 : kontrol negatif (diberi air menggunakan sonde) Kelompok $2: 400 \mathrm{mg} / \mathrm{kgBB} /$ hari $=400 \mathrm{mg} /$ $5000 \mathrm{mg} \times 100 \mathrm{ml}=8 \mathrm{ml}$

$8 \mathrm{ml} \times 0,2 \mathrm{~kg}=1,6 \mathrm{cc} /$ sonde

Kelompok $3: 500 \mathrm{mg} / \mathrm{kgBB} /$ hari $=500 \mathrm{mg} / 5000 \mathrm{mg} \mathrm{x}$ $100 \mathrm{ml}=10 \mathrm{ml}$

$10 \mathrm{ml} \mathrm{x} 0,2 \mathrm{~kg}=2 \mathrm{cc} /$ sonde

Mengambil tikus yang sudah dikelompokkan berdasarkan perlakuan secara satu persatu. Pengambilan tikus dilakukan dengan hati-hati dan perlahan, agar tikus tidak takut dan tidak stress. Tikus dipegang dengan cara memegang badan tikus dan menaruh bagian ekor serta menjepitnya pada jari antara kelingking dengan jari manis, lalu menyilangkan kaki depan tikus dan menjepitnya pada jari antara jari telunjuk dengan jari tengah, sedangkan posisi kepala tikus siap untuk diberi boraks. Kemudian sonde dimasukkan melalui sudut mulut agar tikus tidak menggigit sonde, pemasukan sonde dilakukan ketika tikus melakukan gerakan menelan/ menggerak-gerakkan lidahnya, sehingga sonde tidak melukai bagian dalam mulut tikus. Setelah sonde masuk sampai esofagus baru larutan boraks dimasukkan.

Pembuatan sediaan histologi testis dilakukan dengan cara: Dilakukan potongan secara coronal pada testis kemudian diletakkan pada tabung organ dan fiksasi dengan formalin 10\% selama 24 jam. Dilakukan dehidrasi dengan merendam pada alkohol bertingkat, yaitu pada konsentrasi 50\%, 70\%, 95\% dan 2 kali alkohol absolut masing masing selama 30 menit. Dilakukan clearing dengan menggunakan alkohol dan xilol dengan perbandingan alkohol : xilol (3:1, 1:1, 1:3) dan dua kali xilol murni masing-masing selama 60 menit. Dilakukan proses infiltrasi dengan xilol dan parafin dengan perbandingan $3: 1,1: 1,1: 3$ dan 1 kali parafin murni selama 1 jam pada suhu $46^{\circ} \mathrm{C}-52^{\circ} \mathrm{C}$. Dilakukan blocking dengan parafin keras pada suhu $46^{\circ} \mathrm{C}-52^{\circ} \mathrm{C}$ selama 1 jam.

Kemudian dipotong dengan mikrotom yang berukuran 3-5 milimikron dan potongan direkatkan pada kaca objek .Dipanaskan pada suhu $46^{\circ} \mathrm{C}-52^{\circ} \mathrm{C}$ didalam inkubator selama 24 jam. Dilakukan deparafinisasi yaitu dengan perendaman dengan xilol 2 kali alkohol absolut 95\%, 85\%, 70\%, 50\%, $30 \%$ dan $\mathrm{H} 2 \mathrm{O}$ masing-masing selama 3 menit. Dilakukan pewarnaan Hematoxilin Eosin dengan langkah sebagai berikut: Pemberian Haris Hematoxilin Eosin selama 15 detik. Eosin staining selama 15-20 menit. Dehidrasi pada alkohol bertingkat 50\%,70\%, 85\%, 95\% dan 2 kali alkohol absolut. Pemberian xilol selama 5 menit. Mounting menggunakan perekat entelan. Panaskan pada suhu 46$52^{\circ} \mathrm{C}$ di dalam inkubator selama 24 jam

Diameter testis dihitung dengan menggunakan jangka sorong, berat testis diukur dengan timbangan digital sartorius, dan sediaan diamati dengan mikroskop cahaya pembesaran 100x menggunakan mikroskop olympus cx41 untuk menghitung jumlah tubulus seminiferus pada 5 lapang pandang. 


\section{Analisis Data}

Penelitian ini menggunakan uji ANOVA dengan bantuan SPSS versi 15.00. Uji one way ANOVA yaitu untuk menguji hipotesis kesamaan rata-rata antar kelompok $(>2$ kelompok), apakah rata-rata antar sampel berbeda secara signifikan atau tidak; dengan tingkat kepercayaan á $=0,05$, dimana apabila diperoleh $\mathrm{p}>0,05$ artinya tidak ada perbedaan yang bermakna sebaliknya bila $\mathrm{p}<0,05$ menunjukkan adanya perbedaan yang bermakna. Uji Tukey $5 \%$ merupakan uji kelanjutan dari uji ANOVA digunakan untuk mengetahui perbedaan yang bermakna antara masing-masing kelompok perlakuan dalam penelitian. Uji korelasi digunakan untuk mengetahui hubungan yang signifikan antara dosis boraks dengan atrofi testis tikus putih jantan (rattus norvegicus strain wistar). Analisis regresi untuk mengetahui besar pengaruh pemberian boraks dengan terjadinya atrofi testis tikus putih jantan (rattus norvegicus strain wistar).

\section{HASIL DAN PEMBAHASAN}

Tabel 1. Pengaruh pemberian boraks terhadap diameter testis pada tikus

\begin{tabular}{lc}
\hline \multicolumn{1}{c}{ Perlakuan } & Rerata Diameter Testis $(\mathrm{cm})$ \\
\cline { 2 - 2 } & $\Sigma \pm \mathrm{SD}$ \\
\hline K 1 (Kontrol) & $1,087 \pm 0,025$ \\
K 2 (boraks 400mg kgBB) & $1,038 \pm 0,038$ \\
K 3 (boraks 500mg kgBB) & $1,016 \pm 0,042$ \\
K 4 (boraks 600mg kgBB) & $1,010 \pm 0,059$
\end{tabular}

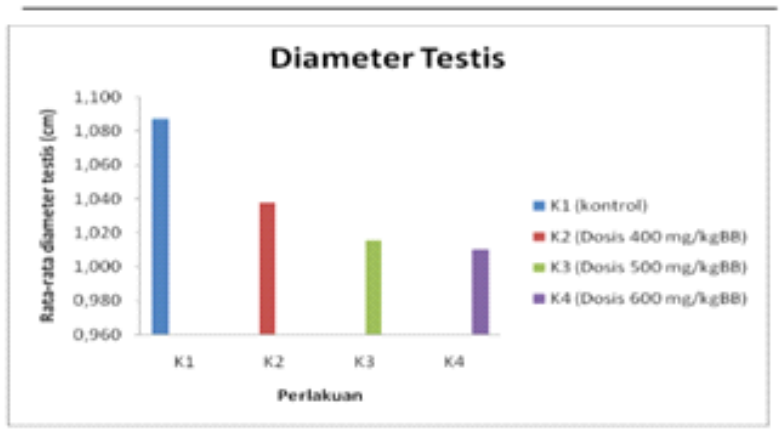

Gambar 1. Pengaruh pemberian boraks terhadap diameter testis pada tikus

Pada gambar 1 dapat dilihat tikus yang diberi boraks akan memiliki diameter testis yang cenderung menurun dibandingkan pada tikus kontrol. Atau dengan kata lain pemberian boraks dengan dosis tertentu, mampu menurunkan diameter testis pada tikus.

Table 2. Pengaruh pemberian boraks terhadap berat testis pada tikus

\begin{tabular}{lc}
\hline \multicolumn{1}{c}{ Perlakuan } & Rerata Berat Testis $(g r)$ \\
\cline { 2 - 2 } & $\Sigma \pm$ SD \\
\hline K I (Keetrol) & $1,005 \pm 0,099$ \\
K 2 (borals 400mg kgBB) & $0,973 \pm 0,078$ \\
K 3 (borals $500 \mathrm{mg} / \mathrm{kgBB})$ & $0,960 \pm 0,051$ \\
K 4 (borals 600mg kgBB) & $0,944 \pm 0,138$ \\
\hline
\end{tabular}

Kelompok 1 yaitu kelompok tikus yang tidak diberi boraks (kontrol) memiliki rerata berat testis sebesar 1,005 dengan standar deviasi sebesar 0,099. Pada kelompok 2, yaitu kelompok tikus yang diberi boraks $400 \mathrm{mg} / \mathrm{kgBB} /$ hari memiliki rerata berat testis sebesar 0,973 dengan standart deviasi sebesar 0,078. Pada kelompok 3, yaitu kelompok tikus yang diberi $500 \mathrm{mg} / \mathrm{kgBB} /$ hari, rerata berat testis mencapai 0,965 dengan standart deviasi sebesar 0,051. Pada kelompok 4, yaitu kelompok tikus yang diberi $600 \mathrm{mg} /$ $\mathrm{kgBB} /$ hari, rerata berat testis menurun hingga mencapai 0,944 dengan standart deviasi sebesar 0,138. Berdasarkan rerata tersebut dapat dikatakan bahwa dengan meningkatkan dosis pemberian boraks dapat menurunkan berat testis pada tikus.

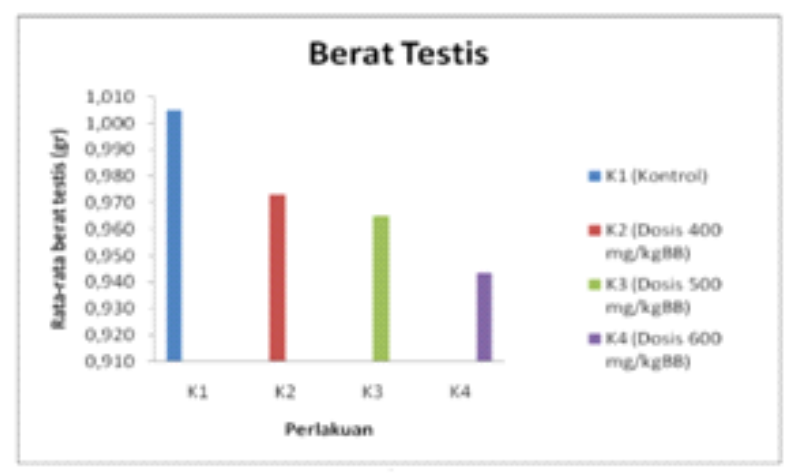

Gambar 2. Pengaruh pemberian boraks terhadap berat testis pada tikus

Tabel 3. Pengaruh pemberian boraks terhadap jumlah tubulus seminiferus perlapangpandang

\begin{tabular}{|c|c|}
\hline \multirow{2}{*}{ Periakuan } & Rerata Jumlah Tubulus seminifierss \\
\hline & $\Sigma \pm S D$ \\
\hline K 1 (Kontrol) & $96,00 \pm 12,49$ \\
\hline K 2 (boraks $400 \mathrm{mg} \mathrm{kg} 33$ ) & $113,3 \pm 11,31$ \\
\hline K 3 (berals 500mg kgBB) & $136,5=7,790$ \\
\hline K 4 (borals 600mg kq3B) & $151,1 \pm 14,55$ \\
\hline
\end{tabular}

Kelompok 1 yaitu kelompok tikus yang tidak diberi boraks (kontrol) memiliki rerata jumlah tubulus sebesar 96 dengan standart deviasi sebesar 12,49. Pada kelompok 2, yaitu kelompok tikus yang diberi boraks $400 \mathrm{mg} / \mathrm{kgBB} / \mathrm{hari}$ memiliki rerata jumlah tubulus sebesar 113,33 dengan standart deviasi sebesar 11,31. Pada kelompok 3, yaitu kelompok tikus yang diberi $500 \mathrm{mg} / \mathrm{kgBB} /$ hari, rerata jumlah tubulus mencapai 136,5 dengan standart deviasi sebesar 7,79. Pada kelompok 4, yaitu kelompok tikus yang diberi $600 \mathrm{mg} / \mathrm{kgBB} /$ hari, rerata jumlah tubulus menurun hingga mencapai 151,17 dengan standart deviasi sebesar 14,55. 


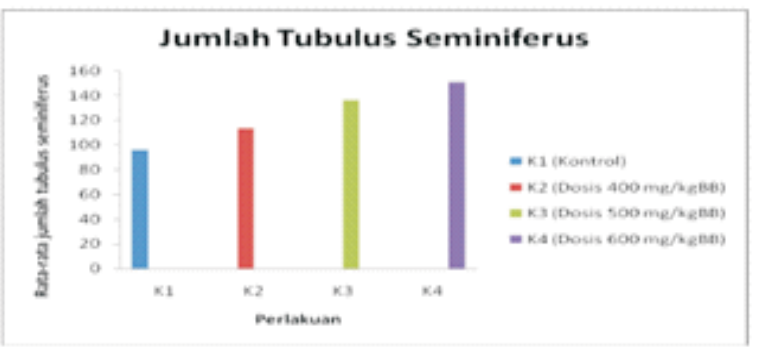

Gambar 3. Pengaruh pemberian boraks terhadap jumlah tubulus seminiferus perlapangpandang

Tikus yang diberi boraks akan memiliki jumlah tubulus yang cenderung meningkat dibandingkan pada tikus kontrol. Atau dengan kata lain pemberian boraks dengan dosis tertentu, mampu meningkatkan jumlah tubulus pada tikus.
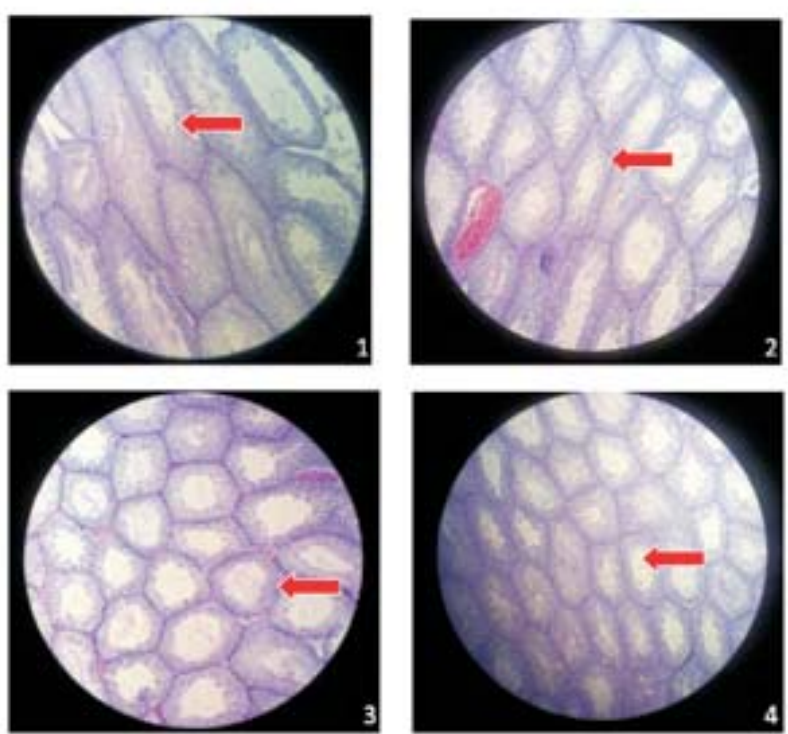

Keterangan:

Gambaran tubulus seminiferus perlapangpandang 1 (dosis boraks $0 \mathrm{mg}$ ), gambar 2 (dosis boraks $400 \mathrm{mg} \mathrm{kgBB}$ ), gambar 3 (dosis boraks $500 \mathrm{mg} \mathrm{kgBB}$ ) dan gambar 4 (dosis boraks $600 \mathrm{mg} \mathrm{kg} B \mathrm{BB}$ ) menggunakan mikroskop pembesaran $100 \mathrm{x}$. Jumlah tubulas seminiferus (tanda panah) pada gambar 4 terlihat paling banyak dibandingkan gambar 1,2, dan 3 .

Boraks merupakan senyawa kimia yang bersifat toksik pada manusia dan hewan. Boraks memiliki ekskresi yang lambat oleh ginjal sehingga pemaparan dalam jangka waktu yang lama menyebabkan terakumulasinya boraks dibeberapa jaringan tubuh seperti otak, hati, lambung, serta organ reproduksi yaitu testis. Sedangkan organ yang paling sensitif terhadap toksisitas boraks yaitu organ testis sehingga efek pemberian boraks pada testis dapat menyebabkan atrofi testis (Pongsavee, 2009).

Mekanisme toksisitas boraks terhadap organ testis dapat menyebabkan terjadinya penurunan yang signifikan dari sintesis DNA. Proses sintesis DNA ini menurun akibat dari menurunnya transportasi H-timidin kedalam sel spermatogonium (ATSDR, 2010) sehingga terhambatnya proses spermatogenesis di tubulus seminiferus (Obregon, 2007). Sel-sel spermatogonium ini merupakan komponen utama pembentuk epitel tubulus seminiferus, jika sel ini terhambat dalam spermatogenesis (proses produksi dan meturitas sperma), maka akan menyebabkan atrofi tubulus seminiferus dan akhirnya terjadilah atrofi testis (Obregon, 2007).

Pada penelitian atrofi tubulus seminiferus yang dilakukan oleh Fukuda (2000) yang dipapar boraks peroral boraks 300 dan $500 \mathrm{mg} / \mathrm{kgBB}$ selama 2 dan 4 minggu didapatkan atrofi tubulus seminiferus sebagian yang dipapar boraks dengan dosis $300 \mathrm{mg} / \mathrm{kgBB}$ dan $500 \mathrm{mg} / \mathrm{kgBB}$ selama 4 minggu. Atrofi tubulus seminiferus ini ditandai dengan pengelupasan sel spermatid, terjadinya retensi proliferasi spermatid pada step 19 yang merupakan tahap penting spermatogenesis untuk menghasilkan sel spermatozoa yang fertil, nekrosis dari spermatosit dan menurunnya jumlah sel sperma di lumen tubulus seminiferus, sedangkan pada dosis $300 \mathrm{mg} / \mathrm{kgBB}$ dan $500 \mathrm{mg} / \mathrm{kgBB}$ selama 4 minggu proses pengelupasan spermatid, retensi proliferasi spermatid, dan nekrosis spermatosit sudah tidak terlihat karena sel-sel spermatogenik ini telah berada di lumen tubulus seminiferus sehingga yang tersisa pada tubulus seminiferus hanya sel sertoli dan sel spermatogonia (sel induk spermatogenik) akibatnya terjadilah atrofi tubulus seminiferus menyeluruh dan akhirnya terjadilah atrofi testis. Atrofi testis ini juga diikuti dengan penurunan berat testis, pemaparan boraks dengan dosis $300 \mathrm{mg} / \mathrm{kgBB}$ dan 500 $\mathrm{mg} / \mathrm{kgBB}$ selama 4 minggu menunjukkan penurunan rerata berat testis dibandingkan selama 2 minggu karena tidak terbentuknya sel-sel spermatogenik yang merupakan komponen utama penyusun epitel tubulus seminiferus.

Pada hasil penelitian ini didapatkan bahwa efek boraks dapat berpengaruh terhadap gambaran mikroskopis testis yaitu jumlah tubulus seminiferus perlapang pandang semakin meningkat tetapi kurang berpengaruh terhadap gambaran makroskopis yaitu diameter dan berat testis hal ini dikarenakan proses penghambatan spermatogenesis belum sempurna yaitu masih terdapat sebagian sel spermatosit dan spermatid pada tubulus seminiferus sehingga atrofi tubulus seminiferus masih sebagian, oleh karena itu pada gambaran makroskopis tidak berpengaruh. Sebagaimana menurut penelitian Obregon (2007) yang meneliti efek boraks terhadap histopatologi dan histometri pada spermatogenesis tikus yang di papar boron $12 \mathrm{mg} / \mathrm{L}$ selama 42 hari didapatkan perubahan histologi testis hanya $27 \%$ sehingga hanya terlihat kerusakan secara mikroskopis yaitu atrofi dari tubulus seminiferus yang ditandai dengan diameter dan tinggi tubulus seminiferus menurun. Hal ini disebabkan oleh efek awal boraks bagi organ testis yaitu terjadinya penghambatan spermatogenesis sehingga sel-sel spermatogonium mengalami penurunan dalam maturitas, jika paparan boraks dilanjutkan dalam jangka waktu lama (sub kronis sampai kronis) maka akan menyebabkan sel-sel spermatogonium benar-benar tidak terbentuk sebagai epitel utama tubulus seminiferus yang akan menyebabkan atrofi testis menyeluruh sehingga menurunkan diameter dan berat testis.

Atrofi testis dapat menyebabkan infertilitas, pada hasil penelitian yang dilakukan oleh Parikh dkk (2011) penyebab infertilitas karena atrofi testis sebesar 11,25\% dan lebih dari $90 \%$ kasus infertilitas pada pria terjadi karena menurunnya 
jumlah sperma dan kualitas sperma, pada atrofi testis terjadi penurunan jumlah sperma karena spermatogenesis tidak berlangsung dengan baik (Hafeez et al, 2011) sehingga jumlah produksi sperma yang dihasilkan $<20$ juta sel/ ml sedangkan jumlah normal sperma $>20$ juta sel $/ \mathrm{ml}$ (Parikh et al, 2011). Atrofi testis tidak hanya dilihat dari jumlah tubulus seminiferus perlapang pandang tetapi dapat juga dihitung melalui jumlah sel-sel spermatogenik, kualitas sel spermatogenik serta diameter dan tinggi tubulus seminiferus. Jika terjadi atrofi testis yang dibuktikan dengan menurunnya jumlah serta kualitas sel spermatogenik maka akan menyebabkan infertilitas, akan tetapi atrofi testis pada penelitian ini belum dapat menyimpulkan terjadinya infertilitas karena hanya menghitung jumlah tubulus seminiferus dan tidak mengevaluasi jumlah serta kualitas dari sel-sel spermatogenik.

\section{SIMPULAN}

Ada pengaruh pemberian boraks peroral sub akut terhadap terjadinya atrofi testis tikus putih jantan (Rattus novergicus strain wistar). Pemberian boraks peroral sub akut dapat menurunkan diameter testis, tidak dapat menurunkan berat testis, dan dapat meningkatkan jumlah tubulus seminiferus testis tikus putih jantan tikus putih jantan. Dosis minimal boraks peroral sub akut yang menyebabkan atrofi testis tikus putih jantan terdapat pada dosis $400 \mathrm{mg} / \mathrm{kgBB}$.

\section{DAFTAR PUSTAKA}

ATSDR (Agency for Toxic Substances and Disease Registry), 2010,Toxicological Profile For Boron, U.S. Department of Health and Human Services, Atlanta [online], (diunduh 20 Januari 2013), tersedia dari: http: // www. atsdr. cdc. Gov / Tox Profiles/ tp26.pdf

Badan Pengawasan Obat dan Makanan, 2009, Kandungan dan Bahaya Boraks dalam Makanan [online], (diunduh 4 April 2012), tersedia dari: http://www.pom.go.id/ index.php/home/berita_aktual/html.

Badan Pengawasan Obat dan Makanan, 2011, Hasil Pengawasan Keamanan dan Mutu Produk Pangan [online], (diunduh 4 April 2012), tersedia dari: http:/ /www. pom.go.id/ppid/rar/LAPTAH_ 2011.pdf

Bennet RL, Wiweko B, Hinting A, et al, 2012, Indonesian Infertility Patients Health Seeking Behaviour and Patterns of Access to Biomedical Infertility Care: An Interview Administered Survey Conducted in Three Clinics, Reproductive Health Journal, 9, pp 24 [online], (diunduh 4 Februari 2013), tersedia dari: http:// www.reproductive-health-journal.com/content/9/1/24

Cahyadi W, 2008, Analisis dan Aspek Kesehatan Bahan Tambahan Pangan, Bumi Aksara, Jakarta [online], (diunduh 12 Februari 2012), tersedia dari: http:// www.bumiaksara.co.id/detail_b_ba.php?id=265.

Cheng YC dan Mruk DD, 2002, Cell Junction Dynamics in the Testis: Sertoli Germ Cell Interactions and Male Contraceptive Development, Physiol Rev, 82: 825-874, New York.
Chandrasoma P dan Taylor, CR, 2006, Ringkasan patologi anatomi, EGC, Jakarta. Cotran R ,Robbin S, Kumar $\mathrm{V}$ et al, 2002, Pathology Basis of Disease sixth edition, W.B SAUNDERS COMPANY, Philadelphia Departemen Kesehatan Republik Indonesia, 1999, Bahan Tambahan Makanan [online], (diunduh 25 November 2012), tersedia dari: http: // hukum. unsrat. ac. id/ men/ menkes_1168_1999.pdf.

Faiz O dan Moffat D, 2003, At a Glance Anatomi, Edisi kedua, Erlangga Medical Series, Jakarta.

Fiore, M.S.H, 2004, Atlas of Human Histology, Edisi V, EGC, Jakarta. Afifah, E. \& Tim Lentera. 2003. Khasiat Dan Manfaat Temulawak Rimpang Penyembuh Aneka Penyakit. PT Agromedia Pustaka, Jakarta. Hal: 2-3, 7 10 ,

Fukuda R, Hirode M, Mori I et al, 2000, Collaborative Work to Evaluate Toxicity on Male Reproductive Organs by Repeated Dose Studies in Rats (Testicular Toxicity of Boric Acid after 2 and 4 Week Administration Periods), Toxicological Sciences, 20, pp. 233239 [online], (diunduh 2 september 2012), tersedia dari: http: // www.ncbi. nlm. nih. gov/ pmc/ articles/ PMC1566649/.

Guyton, A dan Hall, J, 2007, Buku Ajar Fisiologi Kedokteran, EGC, Jakarta. Ganong, FW, 2008, Buku Ajar Fisiologi Kedokteran, EGC, Jakarta

Hafeez M, Ahmed A, Usmanghani K et al, 2011, Clinical Evaluation of Herbal Medicine for Oligospermia, Pakistan Journal of Nutrition 10 (3): 238-240.

Hochschild FZ, Adamson GD, Mouzon JD et al, 2009, International Committee for Monitoring Assisted Reproductive Technology (ICMART) and the World Health Organization (WHO) revised glossary of ART terminology, Fertility and Sterility, Vol 92 No 5.

Junqueire, LC dan Carnneiro J, 2007, Histologi Dasar Teks dan Atlas, EGC, Jakarta. Kass, EJ, 2003, Diagnosis and Treatment of Acute Scrotum, American Familiy Physician, 59, pp. 817-824 [online], (diunduh 12 februari 2012), tersedia dari: http:/ www.aafp.org/ afp/1999/0215/p817.html.

Lutz S, 2009, Blue Histology of Male Reproductive System [online], (diunduh 8 Mei 2012), tersedia dari: http: / / www. lab. anhb. uwa.edu.au/ mb140/ corepages/ malerepro/malerepro.htm.

Mascarenhas MN, Flaxman SR, Boerma T et al, 2010, National, Regional, and Global Trends in Infertility Prevalence Since 1990: A Systematic Analysis of 277 Health Surveys, PLOS Medicine Vol 9. Nasution A, 2010, Analisa Kandungan Boraks Pada Lontong di Kelurahan Padang Bulan Kota Medan Tahun 2009, Fakultas Kesehatan Masyarakat Universitas Sumatera Utara, Medan [online], (diunduh 5 maret 2012), tersedia dari: http://repository.usu.ac.id/bitstream/ 123456789/17797/7/.pdf.

Obregon E, Carvallo M, Belmar H, et al, 2007, Histopathological and Histometrical Assessment of Boro Exposure Effects on Mouse Spermatogenesis, Int. J. Morphol., 25(4):919-925 [online], (diunduh 12 Afrida, Yulinah, E.S. \& Gana, A.S. 1993 Detail 
Penelitian Obat Bahan Alam. (Online). (http://bahanalam.fa.itb.ac.id, diakses: 05 Maret 2008). Januari 2013), tersedia dari:http: // www. scielo. Cl / pdf/ ijmorphol/ v25n4/ art39.pdf

Oktavia, Lambok, 2012, Pengaruh Pengetahuan dan Motif Ekonomi terhadap Penggunaan Formalin dan Boraks oleh Pedagang dalam Pangan Siap Saji (bakso) di Kecamatan Medan Denai dan Medan Tuntungan Tahun 2011, Fakultas Kesehatan Masyarakat Universitas Sumatera Utara, Medan [online], (diunduh 8 Agustus 2012), tersedia dari: http: // repository.usu.ac.id/ bitstream/123456789/33347/7/.pdf.

Olayemi FO, 2010, A Review Some Causes of Male Infertility, African Journal of Biotechnology, 9(20), pp. 28342842 [online], (diunduh 2 Februari 2013), tersedia dari: http://www.academicjournals.org/AJB

Parikh UR, Goswami HM, Deliwala KJ et al, 2011, Testicular Biopsy In Male Infertility (Study Of 80 Cases), The Internet Journal of Pathology, Vol 11 No 2 [online], (diunduh 7 Februari 2013), tersedia dari: http:// www.ispub. com/ journal/the-internet-journal-of-pathology/volume-11 number-2/testicular biopsy - inmale- infertility-study-of-80 cases. html\# sthash. I5A9YEwY.dpbs

Plotnik DA, Emerick LE, Krohn KA et al, 2012, Different Modes of Transport for H-Thymidine, H-FLT, and HFMAUin Proliferating and Nonproliferating Human Tumor Cells, J Nucl Med, 51(9): 1464-1471.

PMRA (Pest Management Regulatory Agency), 2012, Boric Acid and its Salts(Boron), Health Canada Pest Management Regulatory Agency, Canada [online], (diunduh 25 Januari 2013), tersedia dari: http:// www.gardexinc.com/rants/wp-content/uploads / PRVD2012-03-BoricAcid-eng.pdf

Pongsavee, Malinee, 2009, Effect of Borax on Immune Cell Proliferation and Sister Chromatid Exchange in $\mathrm{Hu}-$ man Chromosomes, Occupational Medicine and Toxicology, 4, pp. 1-6 [online], (diunduh 20 April 2012), tersedia dari: http://www.ncbi. nlm. nih.gov/pubmed/ 19878537.

Price, S.A. dan Wilson, L.M, 2005, Patofisiologi, EGC, Jakarta. Purnomo, BB, 2011, Dasar-dasar Urologi, Ed 3, Sagung Seto, Jakarta.

Saparinto C dan Hidayati D, 2006, Bahan Tambahan Pangan, Cetakan I, Kanisius, Yogyakarta. 